Contents lists available at Journal Redwhitepress
Journal of Educational and Learning Studies
ISSN: 2655-2760 (Print) ISSN: 2655-2779 (Electronic)
Journal homepage: http://journal.redwhitepress.com/index.php/jles

\title{
Reveal the Condition of Students' Identity in Facing Pornography
}

\author{
Advis Arin Pramesti ${ }^{1}$, Riska Ahmad ${ }^{1}$, Netrawati $^{1}$ \\ ${ }^{1}$ Universitas Negeri Padang
}

\begin{tabular}{|c|c|}
\hline Article Info & ABSTRACT \\
\hline Article history: & \multirow{8}{*}{$\begin{array}{l}\text { Self-identity has an important role in student development. Failure to cultivate } \\
\text { this quality leads to deviant behavior such as pornography. The purpose of this } \\
\text { study was to describe the identity of students with regard to pornography. The } \\
\text { research methods used were quantitative with a descriptive analysis approach. } \\
\text { The population sample included } 106 \text { public vocational students in the city of } \\
\text { Padang selected by the proportional random sampling technique. The data } \\
\text { collection technique in this study used a questionnaire instrument with a Likert } \\
\text { model scale. The results showed the identity of students have a } 7 \% \\
\text { contribution in identity diffusion conditions, } 32 \% \text { identity foreclosure } \\
\text { conditions, } 48 \% \text { moratorium conditions, and } 13 \% \text { achievement conditions. } \\
\text { The findings of this study might be used by counselors to help students in } \\
\text { forming their own identities especially in the face of pornography. }\end{array}$} \\
\hline Received Feb 12 $2^{\text {th }}, 2019$ & \\
\hline Revised Apr 25 $5^{\text {th }}, 2019$ & \\
\hline Accepted Jul 2 ${ }^{\text {nd }}, 2019$ & \\
\hline Keyword: & \\
\hline Self Identity & \\
\hline Pornography & \\
\hline Student's Identity & \\
\hline
\end{tabular}

(C) 2019 The Authors. Published by Redwhitepress.

This is an open access article under the CC BY-NC-SA license (https://creativecommons.org/licenses/by-nc-sa/4.0/

\section{Corresponding Author:}

Advis Arin Pramesti

Universitas Negeri Padang

Email: advis.arin21@gmail.com

\section{Introduction}

In adolescence, the main goal of student development is developing self-identity (Gunarsa, 2009). A Student understands who he is, niqueness, and the purpose of life. This helps one be aware of the characteristics of personality, such as likes and dislikes, aspirations, future goals, and feelings which helps adjust the orientation of life(Desmita, 2005). During the development of self-identity, students experience an identity crisis, failing to know what to do, how to behave, and how to handle matters in life. Students try to determine who they really are, where to direct life, how to gain recognition from others. This condition leads to uncertainty, though it still depends on their environment (Huriati, 2016).

Formation of self-identity requires two important elements, exploration (crisis) and commitment (Steensma, Kreukels, Vries, \& Cohen-kettenis, 2013). Exploration (crisis) shows a time when someone tries to navigate various alternatives, which in the end set a particular choice. The knowledge possessed by teenagers produces an attitude shown in their lives (Israelashvili, Kim, \& Bukobza, 2012). The term commitment shows the effort to make decisions about work or ideology and determine various strategies to realize the decision made. Commitments make adolescents not easily affected and try to maintain their choices, knowing and understanding the life they live (Rahma, 2013). Self-identity is a subjective feeling about oneself that is consistent and develops from time to time through the process of exploration and commitment as quantified by the Objective Measure of Ego Identity Status (OM-EIS). The criteria were developed by Marcia (JordánConde, Mennecke, \& Townsend, 2014) and include Identity diffusion, Identity foreclosure, Identity moratorium, and Identity achievement. 
Adolescence is often associated with myths and stereotypes about irregularities (Netrawati, Khairani, \& Karneli, 2018). Students violating the norm are most likely tolose direction, not exploring or being committed to certain roles. As a result, they are usually perceived to have low self-identity (Carlsson, Wangqvist, \& Frisen, 2016). Conversely, the better the self-identity, the more active one is, since he or she has explored and made commitments in life (Rahma, 2013). Santrock (2007) also suggests that the development of identity is one of the triggers of delinquency, a trait mainly marked by the failure of adolescents to integrate identity. Likewise, adolescents not able to meet the demands of the roles charged to them are often characterized by negative identities. Generally, they conflict with the expectations of parents or the community. According to Berdibayeva et al., (2016) and Prasasti (2017), individuals with low self-identity tend to show deviant behaviors not acceptable to the community called juvenile delinquency.

The results of Anindyajati (2013) showed that of 40 students, 23 students had achievement identity (20 students were characterized by mild delinquency, and 3 had moderate mischief). Besides, 4 were in the identity moratorium ( 1 person had mild delinquency and 3 medium delinquency) while 9 had identity foreclosure ( 1 person did mild delinquency, 6 people did moderate delinquency and 2 people were severely delinquent). The last 4 were in the diffusion identity ( 1 had mild error and 3 medium delinquency). Based on the results of these studies, one's identity is different, and therefore the delinquency conducted is also different.

Currently, juvenile delinquency is increasingly complicated due to technological developments and globalization. Internet technology offers a variety of facilities for users to access unlimited internet. Things that were previously impossible to do in the real world are very possible, including matters related to sexuality such as pornography (Aryani, 2008). Pornography is often delivered through a variety of media including magazines, books, internet sites, telephone and video services designed to stimulate individuals sexually individuals (Kor et al., 2014). This is problematic behavior, the basis of moral and legal sanctions since it damages the value of morality, undermine the morale of adolescents as well as adults and lead to increased deviant sexual behavior. rape, infidelity, sexual abuse, obscene acts and other similar behavior (Ardi, Viola, \& Sukmawati, 2018; Haryani R, Mudjiran, \& Syukur, 2012).

The results of the study (Ybarra \& Mitchell, 2005) showed $87 \%$ of teens who searched for sexual images online were 14 years or older. According to Supriati \& Fikawati (2009), 83.8\% of adolescents had pornography viewing experience and $79.5 \%$ had faced the effects of exposure. Furthermore, data on teen pornography in Indonesia in 2016 (KPAI, 2016) showin 2011-2015 pornography and cybercrime had a significant increase, though there was a slight decrease in 2016. Nevertheless, it still remains a serious problem, and recent data show it is relatively high (Gewirtz-meydan, Walsh, Wolak, \& Finkelhor, 2018).

Various things that happen among adolescents need to be addressed. Alleviation efforts might be done by anyone, starting from yourself, friends, teachers, parents, and counselors. On an individual basis, teenagers are expected to mark their identity. Puspitasari, Dwi, \& Syaifuddin Latif (2013) explained that one of the causes of the tendency to view pornography was a low self-identity. Quality plays a significant role in the chosen media and information used (Bobkowski, Shafer, \& Ortiz, 2016). Therefore, adolescents are expected to develop self-identity in order to realize who they are, acknowledge their character, and actin accordance with the values and norms. This helps them take precautions against pornography (Porter, 2015).

Counselors as professionals should pay attention to the concept of self-identity through guidance and counseling services in schools. There is a need to provide understanding and help students succeed in developing their identity. Additionally, increasing the tendency to view pornography is facilitated by a lack of information by students (Asmidaryani, Firman, \& Gistituati, 2018). With guiding and counseling services, students obtain effective information through various approaches. The findings of this research might be used as a basis for BK teachers in improving guidance and counseling services in schools, especially handling problems of identity and pornography.

\section{Method}

This was a descriptive quantitative study which describes systematically, factually and accurately the facts relating to the characteristics of the population or explains the phenomenon in detail. The sample population consisted of 106 students from Vocational high school and were selected by a proportional random sampling technique. The data collection technique used was a questionnaire instrument with a Likert model scale. The questionnaires were developed based on sub-variables consisting of diffusion, foreclosure, moratorium, and achievement. The data obtained were analyzed using percentage techniques. As stated by Winarsunu (2012) statistical analysis, percentage techniques are the result of frequency sharing with samples then multiplied by one hundred. 


\section{Results and Discussions}

The results of research on students' self-identity in the face of pornography were analyzed descriptively. The image below shows the percentages.

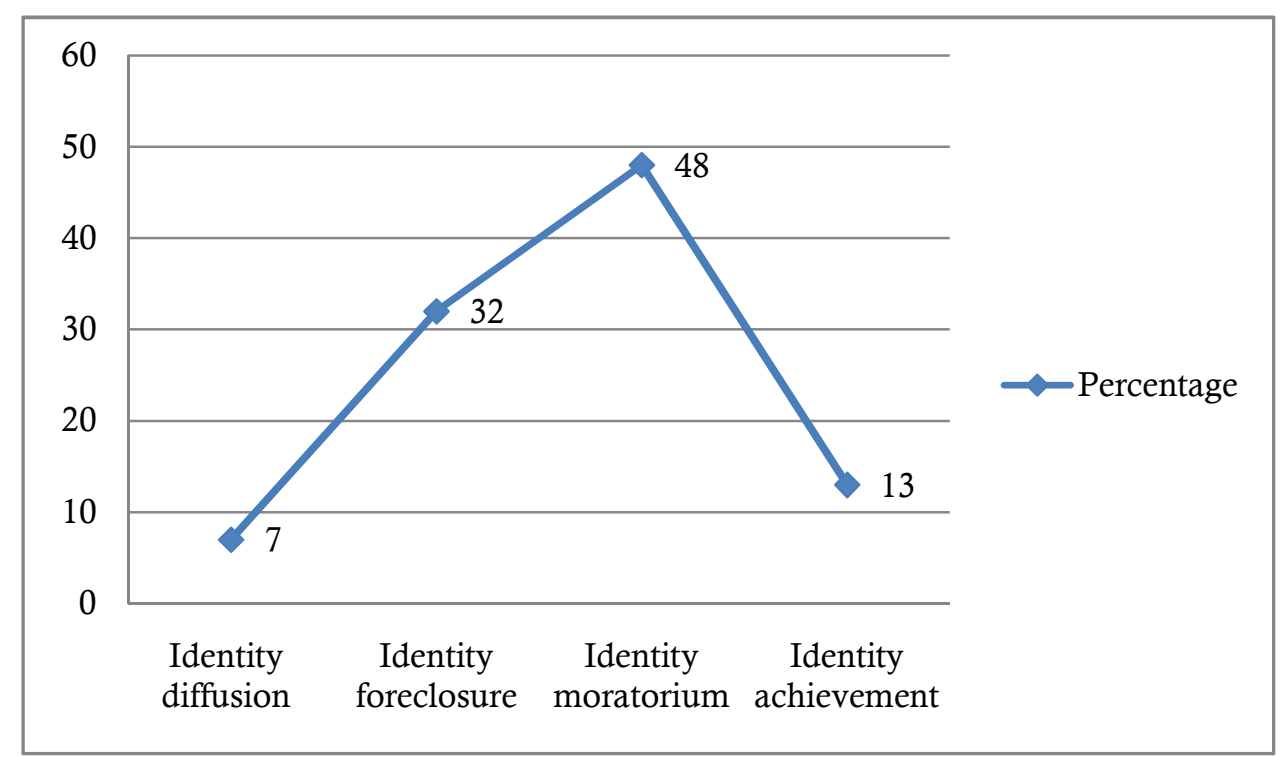

Figure 1. Percentage of Condition of Student Identity in Facing Pornography

The results above are from 106 students who were given questionnaires. Basically,students were in different phases of identity. For instance, $7 \%$ (7 students) were in Diffusion, 32\% (34) foreclosure, $48 \%$ (51) in moratorium, and $13 \%$ (14) in Identity achievement.

The condition of adolescent self-identity experience change, starting from crisis conditions to the stage of achievement (Kroger, Martinussen, \& Marcia, 2010). The results of this study indicate the identity diffusion of adolescent dealing with pornography is $7 \%$, a total of 7 people, showing there are teenagers who experience crises due to pornography. Teens with diffusion identity are not yet committed and are hesitant to explore (Jordán-Conde et al., 2014). In general, they experience confusion regarding who they are and what they want to do with their lives. In addition, adolescents also do not explore various things in their lives, and therefore their understanding remains to be low. Conditions like this allow teenagers to do negative things, one of which is pornography (Yusuf \& Nurihsan, 2009). The lack of commitment to avoid pornography makes teenagers more desperate. Moreover, most adolescents are hesitant to explore information discouraging pornography. This includes finding out what is the reason for the prohibition on, its dangers, and what efforts they need to make to alleviate it. If this condition is left unchecked, the development of self-identity among teenagers will be negatively affected(Gunawan, 2016).

In identity foreclosure, adolescents are committed to gathering information from others and do not explore other sources(Jordán-Conde et al., 2014). The results of this study indicate that identity foreclosure adolescent is $32 \%$, consisting of 34 students. This condition shows that there are still many adolescents who depend on others when it comes to pornographic decisions. Simply put, they rely on other people such as parents, teachers, and peers. In this condition, the role of parents is very important in shaping teens commitment. The magnitude of the influence of parents on children is illustrated through the tendency to provide rules or restrictions that regulate their behavior (Suardiman, 2011). For example, teens try to avoid pornography for fear of being scolded by parents. The commitment students make to avoid pornography comes from the prohibition of parents and not from their hearts.

Compared to interrelation with parents, interaction with peers provides more opportunities for children to develop their identity during adolescence (Idrus, 2005). Positive influence from peers help teens shape their identity. Conversely, the negative influence of peers causes behavioral deviations. In the case of pornography, one source of youth information is peers (Utomo \& Sa'i, 2018). This happens because teenagers spend more time with peers. Therefore, the development of a positive peer environment needs to be facilitated since it is one of the effective ways of reducing juvenile delinquency, especially when it comes to pornography (Bhakti \& Rahman, 2017).

Identity moratorium is a condition in which adolescents doubts their commitments, and therefore they explore (Jordán-Conde et al., 2014). The results of this study indicate the identity moratorium (identity confusion) is in high, $48 \%$ (51students). This shows there are still many teenagers who experience confusion 
when it comes to identity, mainly due to a lack of knowledge and understanding. Therefore, adolescents begin to find out from various sources matters relating to pornography, such as media and teachers at school. In this regard, they review the commitments made through deeper exploration. In-depth exploration helps in seeking additional information, and discussing with others about the commitments that have been made is helpful (Muttaqin \& Ekowarni, 2016). This helps the gain more understanding and confidence to take precautions against pornography.

Exploration leads to commitment, a condition referred to identity achievement (Jordán-Conde et al., 2014). The results of this study indicate identity achievement (achievement of identity) is 13\% (14 students). This shows a few teenagers achieved self-identity on matters pornography. As they grow, adolescents become more successful since they are able to think rationally and make the right decisions (Suardiman, 2011). Adolescents in this category already have knowledge and understanding of pornography. Besides, they have an awareness of ways of preventing pornography and are not easily influenced by others.

The results of this study show there were still many teenagers who lag in self-identity achievement. If this is left unresolved, the tendency to watch pornography is likely to increase in teens. Therefore, efforts to prevent pornography need to be done, and one of the best way isenhancing adolescent self-identity.

\section{Conclusions}

From this research, students are in different phases of self-identity in Padang City Vocational High School. For instance, $7 \%$ are in diffusion, $32 \%$ in foreclosure, $48 \%$ in the moratorium, and $13 \%$ in identity achievement. Evidently, many students are yet to attain identity achievement, especially in dealing with pornography. This should be an issue of concern for counselors as professionals offering guiding and counseling services in schools.

\section{References}

Anindyajati, P. D. (2013). Status Identitas Remaja Akhir: Hubungannya dengan Gaya Pengasuhan Orangtua dan Tingkat Kenakalan Remaja. Character, 1(2), 1-6.

Ardi, Z., Viola, K., \& Sukmawati, I. (2018). An Analysis of Internet Abuses Impact on Children's Moral Development. Jurnal Penelitian Pendidikan Indonesia, 4(1), 44-50.

Aryani, K. (2008). Penerimaan Remaja Terhadap Wacana Pornografi Dalam Situs-Situs Seks Di Media Online. Jurnal Penelitian Dinas Sosial, 7(2), 71-78.

Asmidaryani, Firman, \& Gistituati, N. (2018). The Effectivenes of Layanan Informasi Using Contextual Teaching and Learning ( CTL ) Approach to Degree of Students Pornography Trends. Procedings International Conferences on Education, Social Sciences and Technology, 133-144.

Berdibayeva, S., Garber, A., Ivanov, D., Satybaldina, N., Smatova, K., \& Yelubayeva, M. (2016). Identity Crisis' Resolution Among Psychological Correction of Deviant Behavior of Adolescents. Procedia - Social and Behavioral Sciences, 217, 977-983.

Bhakti, C. P., \& Rahman, F. A. (2017). Implementasi Tarbiyah Project Berbasis Peer Counseling: Alternatif Solusi Perilaku Candu Pornografi. Prosiding Seminar Bimbingan Dan Konseling, 1(1), 104-114.

Bobkowski, P. S., Shafer, A., \& Ortiz, R. R. (2016). Sexual intensity of adolescents' online self-presentations: Joint contribution of identity, media consumption, and extraversion. Computers in Human Behavior, 58, 64-74.

Carlsson, J., Wangqvist, M., \& Frisen, A. (2016). Life on Hold $\square$ : Staying in Identity Diffusion in the Late Twenties. Journal of $A d, 47,220-229$.

Desmita. (2005). Psikologi Perkembangan. Bandung: Remaja Rosdakarya.

Gewirtz-meydan, A., Walsh, W., Wolak, J., \& Finkelhor, D. (2018). Child Abuse \& Neglect The Complex Experience of Child Pornography Survivors. Child Abuse \& Neglect, 80, 238-248.

Gunarsa, S. D. (2009). Dari Anak Sampai Usia Lanjut: Bunga Rampai Psikologi Perkembangan. Jakarta: BPK Gunung Mulia.

Gunawan, A. (2016). Pengaruh Kegiatan Matrikulasi Pendidikan Seks dan Kesadaran tentang Bahaya Pornografi terhadap Karakteristik Peserta Didik. Tsamrah Al-Fikri, 10, 155-172.

Haryani R, M., Mudjiran, \& Syukur, Y. (2012). Dampak Pornografi Terhadap Perilaku Siswa Dan Upaya 
Guru Pembimbing Untuk Mengatasinya. Konselor Jurnal Ilmiah Konseling, 1(1), 1-8.

Huriati, N. H. \&. (2016). Krisis Identitas Diri pada Remaja. Sulesana, 10(1), 49-62.

Idrus, M. (2005). Kepercayaan Eksistensial Remaja Jawa: Studi di Desa Tlogorejo, Purwodadi, Purworejo, Jawa Tengah. Jurnal Psikologi Islam, 1(1), 73-86.

Israelashvili, M., Kim, T., \& Bukobza, G. (2012). Adolescents ' Over-use of the Cyber World - Internet Addiction or Identity Exploration $\square$ ? Journal of Adolescence, 35(2), 417-424.

Jordán-Conde, Z., Mennecke, B., \& Townsend, A. (2014). Late adolescent identity definition and intimate disclosure on Facebook. Computers in Human Behavior, 33, 356-366.

Kor, A., Zilcha-Mano, S., Fogel, Y. A., Mikulincer, M., Reid, R. C., \& Potenza, M. N. (2014). Psychometric development of the Problematic Pornography Use Scale. Addictive Behaviors, 39(5), 861-868.

KPAI. (2016). Data tentang Pornografi oleh Siswa di Provinsi Sumatera Barat.

Kroger, J., Martinussen, M., \& Marcia, J. E. (2010). Identity stat change during adolescence and young adulthood $\square$ : A meta-analysis. Journal of Adolescence, 33, 683-698.

Muttaqin, D., \& Ekowarni, E. (2016). Pembentukan Identitas Remaja di Yogyakarta. Jurnal Psikologi, 43(3), 231-247.

Netrawati, Khairani, \& Karneli, Y. (2018). Upaya Guru BK untuk Mengentaskan Masalah-Masalah Perkembangan Remaja dengan Pendekatan Konseling Analisis Transaksional. Jurnal Bimbingan Dan Konseling Islam, 2(1), 79-90.

Porter, H. E. (2015). International Journal of Educational Development " Say no to bad touches "”: Schools , Sexual Identity and Sexual Violence in Northern Uganda. International Journal of Educational Development, 41, 271-282.

Prasasti, S. (2017). Kenakalan remaja dan faktor penyebabnya. Seminar Nasional Bimbingan Dan Konseling, 1(1), $28-45$.

Puspitasari, Dwi, \& Syaifuddin Latif, R. W. (2013). Deskripsi Perilaku Pornografi Remaja. Alibkin (Jurnal Bimbingan Dan Konseling), 2(3).

Rahma, F. A. (2013). Hubungan antara Pembentukan Identitas Diri dengan Perilaku Konsumtif Pembelian Merchandise pada Remaja. Character, 1(3), 1-6.

Santrock, J. W. (2007). Remaja (Jilid 2, E; B. Widyasinta \& N. I. Sallama, eds.). Jakarta: Erlangga.

Steensma, T. D., Kreukels, B. P. C., Vries, A. L. C. De, \& Cohen-kettenis, P. T. (2013). Hormones and Behavior Gender Identity Development in Adolescence. Hormones and Behavior, 64(2), 288-297.

Suardiman, S. P. (2011). Psikologi Usia Lanjut. Yogyakarta: Gadjah Mada University Press.

Supriati, E., \& Fikawati, S. (2009). Efek Paparan Pornografi Pada Remaja SMP Negeri Kota Pontianak Tahun 2008. Makara. Sosial Humaniora, 13(1), 48-56.

Utomo, S. T., \& Sa'i, A. (2018). Dampak Pornografi terhadap Perkembangan Mental Remaja di Sekolah. Jurnal Elementary, 6(1), 166-188.

Winarsunu, T. (2012). Statistik dalam Penelitian Psikologi Pendidikan. Malang: UMM Press.

Ybarra, M. L., \& Mitchell, K. J. (2005). Exposure to Internet Pornography among Children and Adolescents: A National Survey. CyberPsychology \& Behavior, 8(5), 473-486.

Yusuf, S., \& Nurihsan, J. (2009). Landasan Bimbingan dan Konseling. Bandung: Remaja Rosdakarya. 